Article

\title{
Activated Carbon and Coconut Coir with the Incorporation of ABR System as Greywater Filter: The Implications for Wastewater Treatment
}

\author{
Zakir Sabara ${ }^{1, *(\mathbb{D}}$, Aswariani Anwar ${ }^{1}$, Setyawati Yani ${ }^{1}$, Kusnul Prianto ${ }^{2}$, Rahmad Junaidi ${ }^{2}$, Rofiqul Umam ${ }^{3}$ (i) \\ and Rizqi Prastowo ${ }^{4}$
}

check for

updates

Citation: Sabara, Z.; Anwar, A.; Yani, S.; Prianto, K.; Junaidi, R.; Umam, R.; Prastowo, R. Activated Carbon and Coconut Coir with the Incorporation of ABR System as Greywater Filter: The Implications for Wastewater Treatment. Sustainability 2022, 14, 1026. https://doi.org/10.3390/ su14021026

Academic Editors: Federica Raganati and Paola Ammendola

Received: 26 December 2021

Accepted: 11 January 2022

Published: 17 January 2022

Publisher's Note: MDPI stays neutral with regard to jurisdictional claims in published maps and institutional affiliations.

Copyright: (C) 2022 by the authors. Licensee MDPI, Basel, Switzerland. This article is an open access article distributed under the terms and conditions of the Creative Commons Attribution (CC BY) license (https:/ / creativecommons.org/licenses/by/ $4.0 /)$.
1 Department of Chemical Engineering, Faculty of Industrial Technology, Universitas Muslim Indonesia, Makassar 90231, Indonesia; aswariani28@gmail.com (A.A.); wati.yani@umi.ac.id (S.Y.)

2 Faculty of Science and Technology, UIN Sunan Ampel Surabaya, Surabaya 60237, Indonesia; kusnul_prianto@uinsby.ac.id (K.P.); rahmad_junaidi@uinsby.ac.id (R.J.)

3 Department of Applied Chemistry for Environment, Kwansei Gakuin University, Sanda 669-1337, Japan; rofiqulumam.geoscience@gmail.com

4 Mining Engineering, Institut Teknologi Nasional Yogyakarta, Yogyakarta 55281, Indonesia; rizqi@itny.ac.id

* Correspondence: zakir.sabara@umi.ac.id

\begin{abstract}
Greywater refers to wastewater generated from domestic activities, which do not contain fecal contamination. Therefore, this study aims to treat greywater in Makassar city to speed up the water cycle and enable reuse, as an environmental conservation strategy. The water parameters measured were pH, Turbidity, Total Suspended Solid (TSS), Biological Oxygen Demand (BOD), and Chemical Oxygen Demand (COD). According to the results, the greywater's BOD, COD, and TTS contents were 49.98 to $54.88 \mathrm{mg} / \mathrm{L}, 509$ to $655 \mathrm{mg} / \mathrm{L}$, and 404.40 to $464.65 \mathrm{mg} / \mathrm{L}$, respectively, all of which exceed $\mathrm{WHO}$ wastewater quality standards. The use of a wastewater treatment installation comprising a combination of Activated Carbon (AC) and Coconut Coir (CC) with the incorporation of the Anaerobic Baffle Reactor (ABR) system as a greywater filter successfully reduced the city's greywater pollution. In addition, the new BOD content fulfills the environmentally safe wastewater standards, while the new COD and TSS contents were $152 \mathrm{mg} / \mathrm{L}$ to $184 \mathrm{mg} / \mathrm{L}$ and $59.68 \mathrm{mg} / \mathrm{L}$ to $77.42 \mathrm{mg} / \mathrm{L}$, respectively, which are close to the WHO domestic wastewater quality standards.
\end{abstract}

Keywords: activated carbon; coconut coir; biological oxygen demand; greywater filter; chemical oxygen demand; $\mathrm{pH}$

\section{Introduction}

In Indonesia, wastewater pollution remains a significant challenge. Wastewater is generated from domestic and industrial usage, as well as from rainfall runoff, and usually contains substances that tend to interfere with environmental sustainability [1]. Based on the source of production, wastewater is categorized into two major types: Domestic, which is discharged from housing, offices, trade, buildings as well as similar facilities, and industrial, which is discharged from factories [2].

Domestic wastewater is further categorized into two types: Greywater and blackwater. Greywater refers to wastewater generated from domestic activities, which do not contain fecal contamination, for instance, dishwashing, laundry, and baths, and is considered to be less polluted, compared to industrial wastewater [2,3]. Meanwhile, blackwater refers to wastewater with fecal contamination [4].

The organic, inorganic, and gaseous contents [5] of domestic sewage have the capacity to pollute the environment and cause various diseases [3]. In addition, some of these materials are decomposed by microorganisms into compounds with unpleasant odors [6]. Wastewater comprises $99.7 \%$ water and $0.3 \%$ foreign materials, including organic and inorganic solids, colloids, and dissolved materials [7]. 
The properties of wastewater are categorized into physical parameters, for instance, color, temperature, turbidity, and odor; chemical parameters, for instance, BOD, COD, pH, and the content of hazardous chemicals, including nitrogen, phosphorus, and chloride; as well as biological parameters, which refer to the content of various living organisms, including fungi, bacteria, and similar aquatic organisms [7,8]. Wastewater treatment technology is a key aspect of environmental conservation aimed at removing pollutant materials from wastewater using three treatment methods: Physical processing, chemical processing, and biological processing [9].

In Indonesia, the water crisis has become a major problem comprising excessive water consumption in certain sectors (domestic, office, industrial, public facilities, as well as social facilities), improperly managed distribution clean water distribution, and scarcity of potable water. According to the distribution of domestic water consumption in Indonesia, about $80 \%$ of the water used for daily domestic activities is wasted; however, this water has the potential to be recycled and reused including $4.3 \%$ for consumption, $4.0 \%$ for toilet, $64.8 \%$ for washing, $13.4 \%$ for vehicle wash, and $13.5 \%$ for watering plants [10].

To minimize the pollution of water bodies by domestic wastewater in Makassar City, the appropriate technology strategies must be implemented to increase the effectiveness of domestic wastewater treatment. Currently, the city's greywater wastewater treatment facilities are poorly managed and financed. This means a low-cost wastewater treatment strategy must be implemented as an environmental management effort. Furthermore, the greywater quality parameters must be measured before and after treatment to determine whether the water fulfills the WHO standards or requires further processing [11].

\section{Chemical Interaction Process and Material Properties}

Previous studies investigated the filtration process using a combination of a GravityDriven Membrane (GDM) and Granular Activated Carbon (GAC) [12]. Generally, this combination is similar to ABR and Membrane Filters with AC as the main composition [13]. Filtration with GDM-GAC comprises physical, chemical, and biological processes, and has been proven to remove suspended and colloidal particles, as well as microorganisms present in water [14].

According to other studies, the use of layered filters with a single layer of sand $(0.55 \mathrm{~m}$ thick) is effective in the retention of solids in suspension, such as algae, and other organic materials. A study on the removal of pesticides and nitrates from water by deep filtration reported significant nitrate removal using sand materials [15]. The sand filter system improves water quality significantly, consequently providing high efficiency in removing turbidity and suspended solids.

In addition to removing turbidity and odor from water, sand-filtering technology and activated carbon effectively remove viruses, bacteria, protozoa, and algae. Turbidity generally refers to the measure of the transparency of a fluid containing particulate matter in the form of inorganic solids (for instance, mud, sand, or clay) or organic matter (for instance, algae and bacteria) [16]. A previous study investigated the development of a filtration system with sand, gravel, and activated carbon (Figure 1) for rainwater treatment [9] and discovered that activated carbon obtained from coconut shells and activated using salt produced an effluent that fulfilled drinking water standards [5] for parameters of $\mathrm{pH}$, Dissolved Oxygen (DO), Biochemical Oxygen Demand (BOD), Chemical Oxygen Demand (COD), and Total Suspended Solids (TSS). Table 1 shows the physicochemical properties of the filtration materials analyzed in a previous study [17]. 


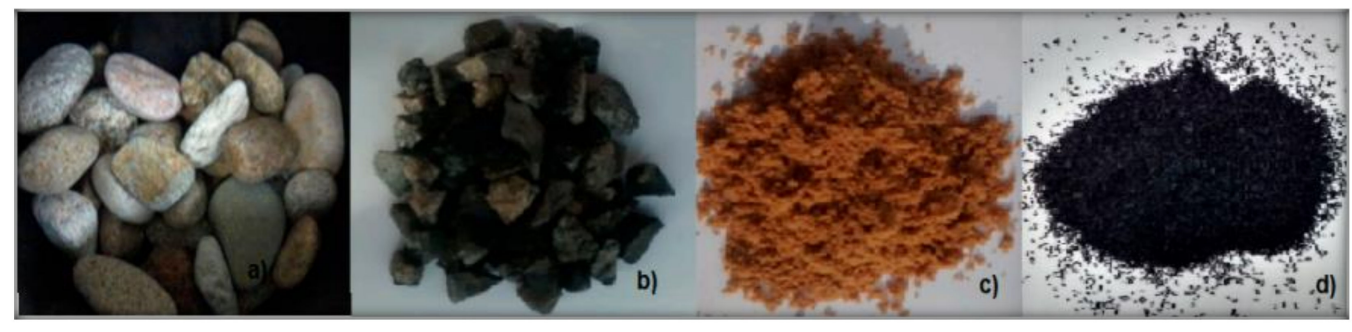

Figure 1. Images of the filtration materials: (a) Rolled pebbles; (b) gravel; (c) sand; (d) activated carbon.

Table 1. The average values and standard deviation of the parameters used for the physicochemical characterization of sand, gravel, and activated carbon [9]. Adopted with permission from Teixeira, C.A. and Ghisi, E (2019).

\begin{tabular}{llll}
\hline Parameter & Sand & Gravel & Activated Carbon \\
\hline $\mathrm{pH}$ & $6.8 \pm 0.1$ & $8.8 \pm 0.1$ & $6.7 \pm 0.1$ \\
Volatile matter content $(\%)$ & $1.0 \pm 0.1$ & $2.9 \pm 0.1$ & $50.8 \pm 0.1$ \\
Moisture content $(\%)$ & $2.38 \pm 0.01$ & $0.05 \pm 0.01$ & $48.73 \pm 0.01$ \\
Ash content $(\%)$ & $1.11 \pm 0.01$ & $6.96 \pm 0.01$ & $6.25 \pm 0.01$ \\
Specific mass $\left(\mathrm{g} / \mathrm{cm}^{3}\right)$ & $2.61 \pm 0.01$ & $2.69 \pm 0.01$ & $1.27 \pm 0.01$ \\
Bulk density $\left(\mathrm{g} / \mathrm{cm}^{3}\right)$ & $1.47 \pm 0.02$ & $1.38 \pm 0.02$ & $0.63 \pm 0.02$ \\
Void index $(\%)$ & $43.8 \pm 0.1$ & $48.8 \pm 0.1$ & $32.9 \pm 0.1$ \\
Iodine number $(\mathrm{mg} / \mathrm{g})$ & - & - & $665.85 \pm 0.01$ \\
\hline
\end{tabular}

Based on particle size, activated carbon is generally categorized as powdery or granular (PAC of GAC, respectively). PAC has a particle size $<80 \mu \mathrm{m}$, with an average size of 10 to $50 \mu \mathrm{m}$, while GAC has a larger particle size of 0.2 to $5 \mathrm{~mm}$ [18]. Another form of activated carbon is powder AC, which has been compressed with a thermoplastic binder (beam AC) [19]. An activated carbon block was developed as a substitute for asphalt, which passes water up to $80 \%$ quicker compared to conventional asphalt. However, due to the present challenge of microplastic pollution, powder $\mathrm{AC}$ with thermoplastic compression is not recommended for water filters [20].

\section{Materials and Methods}

This study was conducted from April 2021 to August 2021, in several stages: The preparation stage, data collection, pre-treatment analysis, filtration, and post-treatment analysis. The filtering process comprised three stages: Coagulation and flocculation in wastewater, physical separation with an Anaerobic Baffle Reactor (ABR) system, and chemical separation with Active Carbon (AC) and Coconut Coir (CC) as the Membrane Filter (MF).

Wastewater sampling was performed before and after the filtration process at 3 points of office locations and business centers around Dr. Ratulangi street, Makassar, Indonesia (Figure 2), as well as at the point where the sewer enters the city's water flow. Meanwhile, the laboratory analysis was carried out at the Oceanography Laboratory, Faculty of Marine and Fishery Sciences, Hasanuddin University, Makassar, Indonesia, using the parameters of Turbidity, $\mathrm{pH}, \mathrm{BOD}, \mathrm{COD}$, and TSS. 


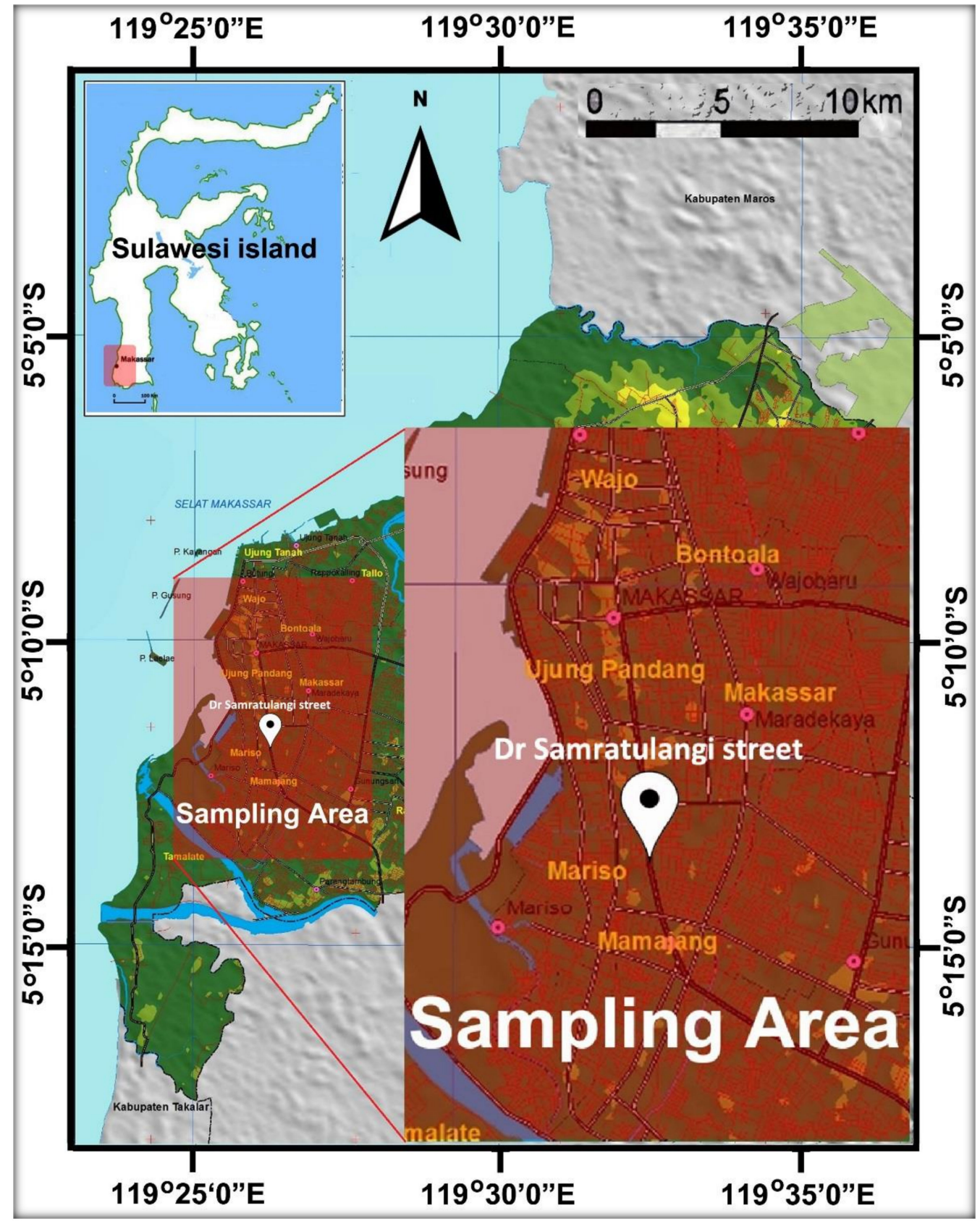

Figure 2. A map of the sampling site in Dr. Ratulangi street, Makassar, Indonesia.

\subsection{Coagulation and Flocculation Processes}

The coagulation process refers to the destabilization of colloidal particles by adding a chemical compound called a coagulant, for instance, alum, lime, Powder Active Carbon (PAC), polyelectrolyte, and any other substance that has the ability to neutralize the colloidal charge and bind the particles into flocs or agglomerates [21]. In industrial wastewater treatment, the coagulation-flocculation process reduces turbidity and improves the effluent's color. A previous study defined coagulation as the process of adding coagulant into the water treatment system to agglomerate fine particles, enabling more rapid settling, and in some cases, eliminating the pathogens present $[22,23]$.

Coagulation and flocculation processes are closely related because the flocculation process' success depends on the coagulation process [16]. These two processes require certain chemicals to aid the formation of floc and are influenced by several factors, including the concentration of coagulant to be added, temperature, $\mathrm{pH}$, and alkalinity [11]. The 
coagulant concentration used must be adjusted to the wastewater's properties and the optimum coagulant concentration is usually determined using the Jar test. The Jar test is a test of a sample that is inserted into a bottle to see if there is a change in the color of the water sample if it is left for a long time [2]. Generally, samples containing oxide, hydroxide, carbonate, or sulfide with an acidic $\mathrm{pH}$ will be easily oxidized in a closed bottle [3]. Several factors influence the coagulation process, including the water quality parameters, for instance, dissolved gases content, color, turbidity, taste, odor, and hardness [23]. Figure 3 shows the coagulation and flocculation processes.

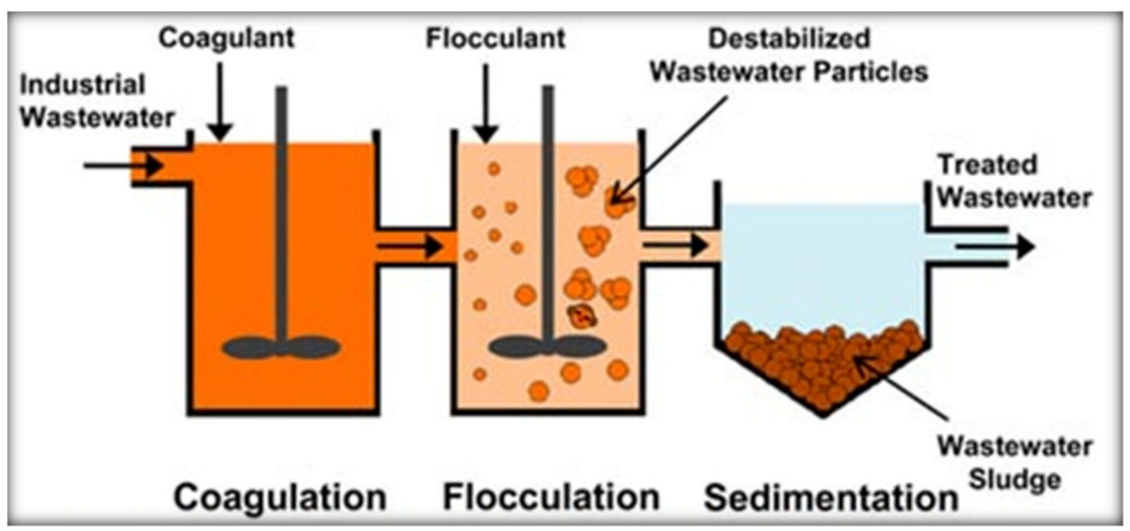

Figure 3. A diagrammatic representation of the wastewater coagulation and flocculation processes.

\subsection{Anaerobic Baffled Reactor (ABR) Process}

An Anaerobic Baffle Reactor (ABR) is used for physical wastewater treatment, which is the foremost stage of wastewater treatment, aimed at removing large and easily settleable suspended or floating materials [24,25]. Common physical processes used for greywater treatment include screening, sedimentation, flotation, and others [25].

The screening process is usually the first process carried out to prevent solid materials, for instance, leaves and non-biodegradable objects, which tend to interfere with subsequent treatment stages. Meanwhile, sedimentation refers to the deposition of colloidal particles, which are suspended by gravity because the specific gravity of the particles is greater, compared to the density of water. In cases where particles with lower density are found, the sedimentation process is usually accompanied by a coagulation process. Subsequently, flotation is carried out to separate any floating materials, including oil and fat, which can interfere with the later treatment stages [26].

\subsection{Membrane Filter (MF) Process with Activated Carbon (AC) and Coconut Coir (CC)}

MF is used for chemical wastewater treatment, which is aimed at removing nonsettling particles, heavy metals, phosphorus compounds [27], and toxic organic substances [9]. Common chemical processes used for greywater treatment include ion exchange filtration [15].

Ion exchange treatment uses ion exchange resins with dissolved salts (ions) in water, while AC treatment is carried out to remove aromatic compounds (for instance, phenol) and other dissolved organic compounds, specifically in cases where the wastewater is intended for reuse. Chemical wastewater treatment processes are highly effective, but equally expensive due to the cost of acquiring the required chemicals [28].

This study performed an MF process with PolyVinyl Chloride (PVC) pipe as a container, as well as AC, CC, gravel, and sand. Based on Figure 4, wastewater flows by gravity through a tap installed below the treated water reservoir to regulate the effluent [29]. 


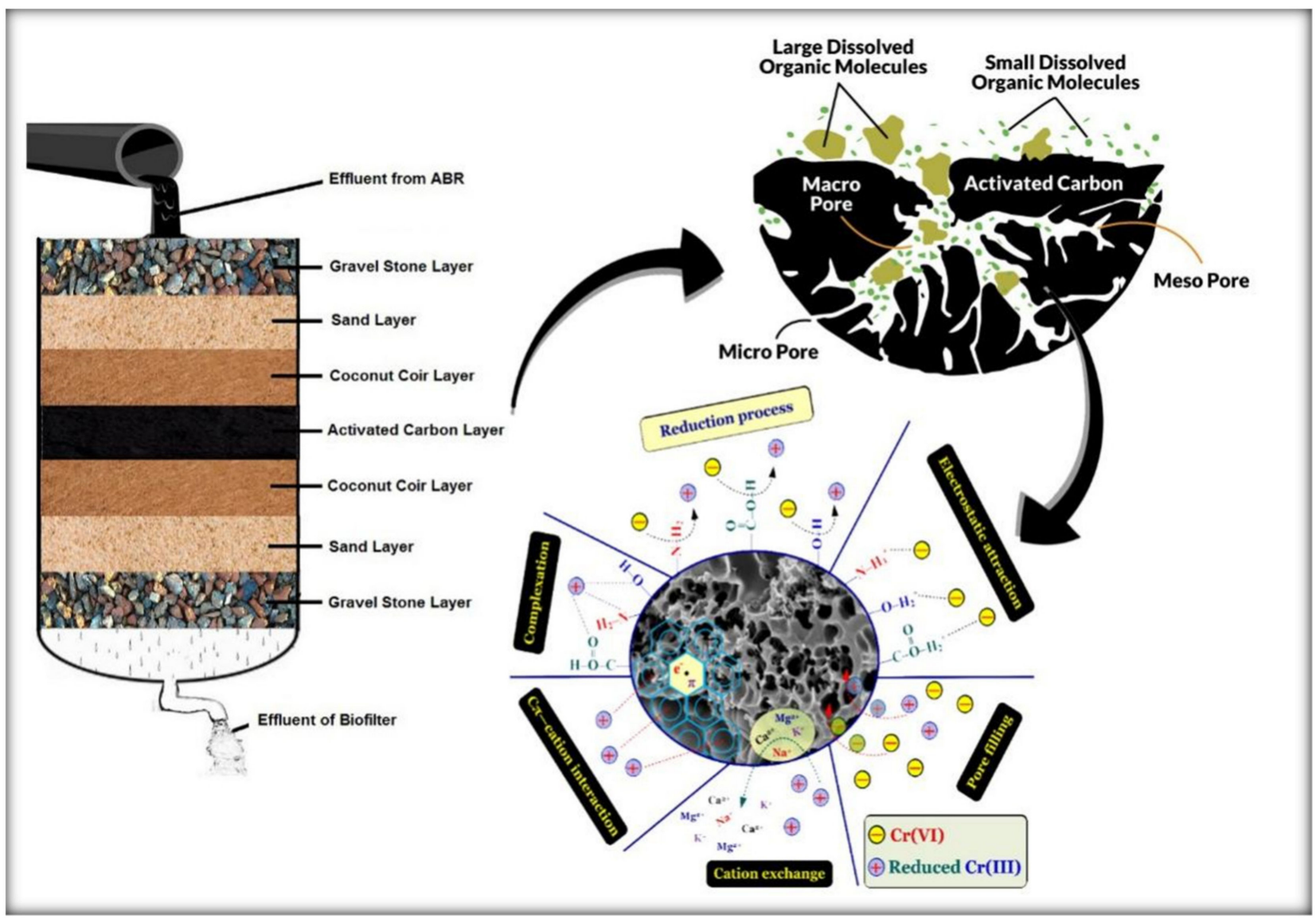

Figure 4. A schematic representation of MF with seven layers (AC and CC as main materials). AC's powerful absorbency capacity can soak up both large and small organic molecules into its pores [28]. Adopted with permission from Tran, H.N. and Chao, H.P (2019).

Based on the internal structure, $\mathrm{AC}$ has heterogeneous-diameter pores ranging from macro $(>50 \mathrm{~nm})$ to meso $(2-50 \mathrm{~nm})$ and micro $(<2 \mathrm{~nm})$ sizes. All pores in AC have highly branched internal porosity (Figure 4), which serves the major function of binding adsorbate species. Meanwhile, based on the chemical structure, AC is categorized as graphite [18]. Certain unwanted impurities or chemicals in water tend to combine with $\mathrm{AC}$, forming various functional groups, for instance, phenols, carboxylic acids, and pyridines. The elemental composition of $\mathrm{AC}$ is $80 \%$ carbon, and $20 \%$ is oxygen, as well as nitrogen. Consequently, the physical and chemical properties of $\mathrm{AC}$ are bound to influence the adsorption capacity for different organic and inorganic species [7].

The greywater filter (wastewater treatment) is a combination of ABR and MF technologies. This tool can be regarded as a low-cost filter manufactured with easily obtainable, environmentally friendly, and easy-to-use materials. A portable greywater filter is an alternative technology equipped with sedimentation and a purification chamber [18]. Figure 5 is a sketch of a series of a greywater filter with $\mathrm{ABR}$ and MF technologies showing the compartments assigned to (a) the initial waste collection tank for coagulation and flocculation; (b) the wastewater catchment tank (ABR); (c) the membrane filter (biofilter with 7 layers) reactor; and (d) the final treated wastewater (greywater). 


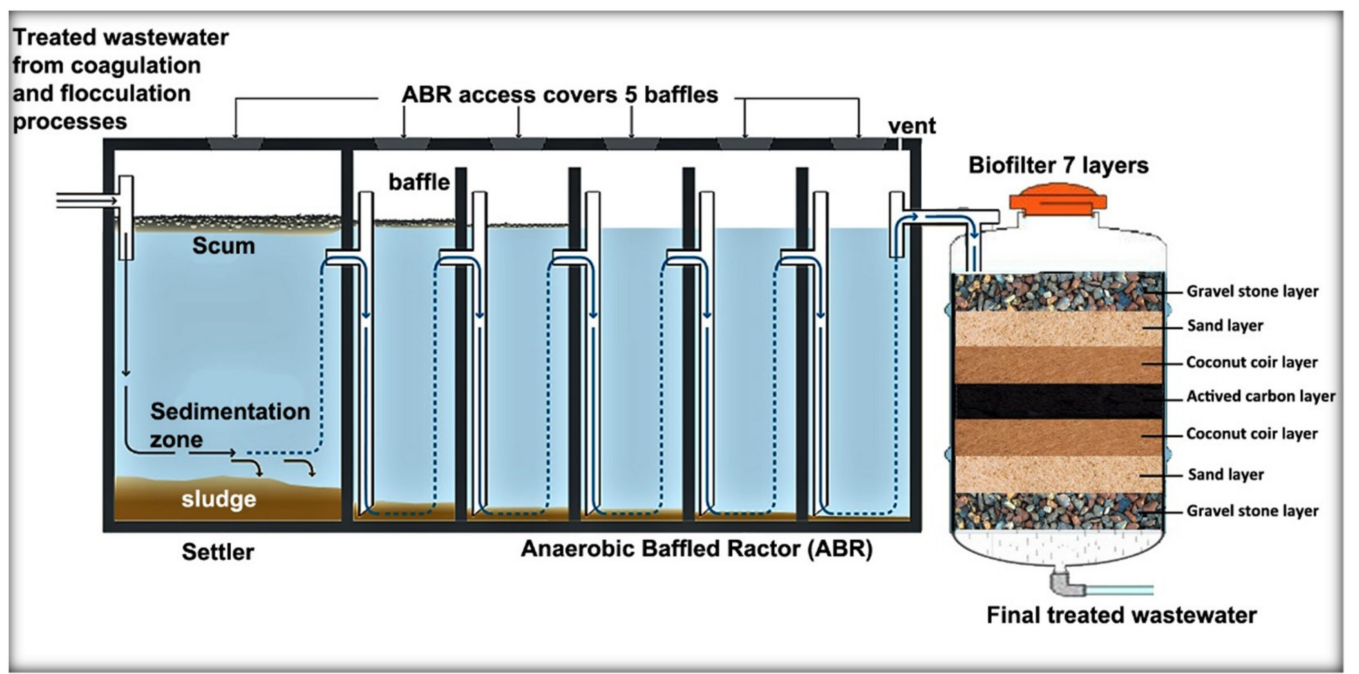

Figure 5. A schematic representation of the greywater filter using a combination of Anaerobic Baffled Reactor (ABR) and Membrane Filter (MF) technologies. Modifed from [25].

\section{Results}

The determination of water content was carried out by various methods such as potentiometry for $\mathrm{pH}$, Winkler titration for $\mathrm{BOD}$ levels, spectrophotometry for $\mathrm{COD}$, and gravimetry for TSS. The Winkler titration method is one of the methods used to determine the oxygen content in water based on an oxidation-reduction reaction [30]. Table 2 shows the results of the laboratory analysis performed before the filtering process.

Table 2. The quality parameters of the greywater before filtering and the results of laboratory analyses performed on the greywater samples AL 1 and AL 2, after the filtration, using sample AL 3 as control (without filtration).

\begin{tabular}{|c|c|c|c|c|c|c|c|c|}
\hline \multirow{2}{*}{ No } & \multirow{2}{*}{ Parameter } & \multirow{2}{*}{ Method } & \multirow{2}{*}{ Unit } & \multicolumn{3}{|c|}{ Sample Value } & \multirow{2}{*}{$\begin{array}{c}\text { Maximum } \\
\text { Limit (WHO) }\end{array}$} & \multirow{2}{*}{ Information } \\
\hline & & & & AL 1 & AL 2 & AL 3 (Control) & & \\
\hline \multirow{5}{*}{ Before } & Turbidity & Turbidimetry & NTU & 313 & 257 & 108 & - & - \\
\hline & $\mathrm{pH}$ & Potentiometry & - & 6.23 & 5.96 & 7.62 & $6-9$ & $\mathrm{E}$ \\
\hline & BOD & Winkler Titration & $\mathrm{mg} / \mathrm{L}$ & 49.98 & 54.88 & 14.7 & 30 & $\mathrm{NE}$ \\
\hline & COD & Spectrophotometry & $\mathrm{mg} / \mathrm{L}$ & 655 & 509 & 284 & 100 & $\mathrm{NE}$ \\
\hline & TSS & Gravimetry & $\mathrm{mg} / \mathrm{L}$ & 464.65 & 404.40 & 181.63 & 30 & $\mathrm{NE}$ \\
\hline \multirow{5}{*}{ After } & Turbidity & Turbidimetry & NTU & 48.73 & 16.25 & 108 & - & - \\
\hline & $\mathrm{pH}$ & Potentiometry & - & 6.78 & 6.86 & 7.62 & $6-9$ & $\mathrm{E}$ \\
\hline & BOD & Winkler Titration & $\mathrm{mg} / \mathrm{L}$ & 19.40 & 17.80 & 14.7 & 30 & $\mathrm{E}$ \\
\hline & COD & Spectrophotometry & $\mathrm{mg} / \mathrm{L}$ & 184 & 152 & 284 & 100 & $\mathrm{NE}$ \\
\hline & TSS & Gravimetry & $\mathrm{mg} / \mathrm{L}$ & 77.42 & 59.68 & 181.63 & 30 & $\mathrm{NE}$ \\
\hline
\end{tabular}

$\mathrm{AL}=$ Greywater; $\mathrm{E}=$ Eligible; NE = Not Eligible; AL3 = control (without filtration).

Based on Table 2 (before the filtering process), the BOD, COD, and TSS levels for samples AL1 and AL2 did not fulfill the WHO quality standards of wastewater, therefore they required further treatment to reduce the level of pollution [25]. The coagulationflocculation process was expected to slightly reduce the greywater's $\mathrm{pH}, \mathrm{BOD}, \mathrm{COD}$, and TTS. According to previous studies, the success of the coagulation and flocculation processes not only affected the $\mathrm{pH}, \mathrm{BOD}, \mathrm{COD}$, and TTS values but also affected the temperature [7].

The greywater filter with ABR and MF system comprises two parts: The main part, which is the gravity system reservoir, and the layer material part for filtering/absorption of chemical compounds [25]. The function of the ABR is to filter out large waste, for instance, moss, stone, and other sediments. Subsequently, the wastewater that enters the biofilter 
layer (MF) experiences a "water-rock interaction" process, as in the concept of ion-exchange chromatography [14].

The greywater filter using ABR and MF technologies was tested on samples AL1 and AL2, which were highly polluted, based on the domestic wastewater quality standard threshold [31]. In the experiment, a significant improvement in the greywater turbidity was observed after the trial, while Table 2 (after filtering process) shows the $\mathrm{pH}, \mathrm{BOD}, \mathrm{COD}$, and TSS values of the greywater after passing through the greywater filter.

\section{Discussion}

\section{1. $p H$ (Degree of Acidity)}

Based on the $\mathrm{pH}$ measurements performed using the potentiometric method, the new $\mathrm{pH}$ levels fulfill the quality standards set by WHO [11]. The acidity of water is determined by the concentration of hydrogen ions and affects the survival of biological life in water. The normal $\mathrm{pH}$ for aquatic life is 6 to 9, and microorganisms are unable to survive in extreme $\mathrm{pH}$ conditions [32]. According to the results, the $\mathrm{pH}$ of the greywater before and after filtration using $\mathrm{ABR}$ and $\mathrm{MF}$ were within the WHO standards for greywater [13]. However, filtration with ABR and MF increased the $\mathrm{pH}$ of samples AL 1 and AL 2 from 6.23 and 5.96 to 6.78 and 6.86, respectively. This is probably due to AC's ability to balance the $\mathrm{pH}$ of water. Figure $6 \mathrm{~A}$ shows $\mathrm{AC}$ is effective in neutralizing the $\mathrm{pH}$ of wastewater, and this is consistent with previous studies where similar results were reported. The error bar in Figure 6A-D describes the range of tolerances in all types of tests being measured.

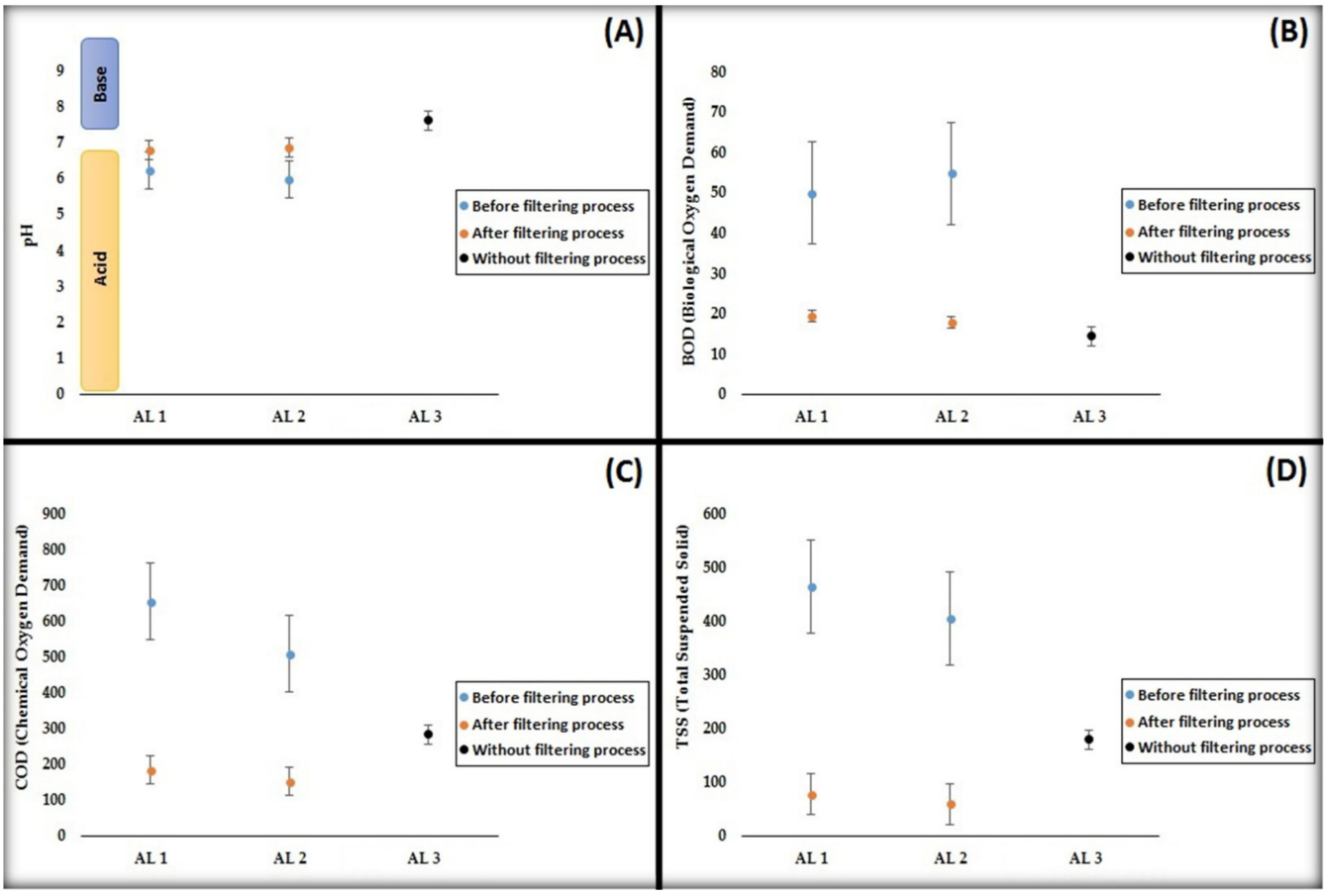

Figure 6. (A) Changes in the $\mathrm{pH}$ (degree of acidity) of greywater before and after greywater filtering; (B) changes in the BOD (Biological Oxygen Demand) before and after greywater filtering; (C) changes in COD (Chemical Oxygen Demand) before and after greywater filtering; (D). Changes in TSS levels before and after greywater filtering. AL 1 and AL 2 are greywater samples after the filtration, AL 3 is control sample (without filtration).

\subsection{BOD (Biological Oxygen Demand)}

BOD refers to the level of oxygen required by microorganisms to decompose or oxidize organic matter in water [13]. The high level of BOD in the greywater before processing indicates the presence of liquid waste, which is hard to decompose properly [26]. This shows the need for a microbial treatment to completely decompose the organic pollutants 
present in wastewater [16]. The BOD test performed using the Winkler titration method obtained values of $49.98 \mathrm{mg} / \mathrm{L}$ and $54.88 \mathrm{mg} / \mathrm{L}$ for samples AL1 and AL2, respectively. These values exceed the WHO standard threshold for domestic wastewater $(30 \mathrm{mg} / \mathrm{L})$.

A significant reduction in the greywater's BOD levels to $19.4 \mathrm{mg} / \mathrm{L}$ and $17.80 \mathrm{mg} / \mathrm{L}$ for samples AL 1 and AL 2, respectively, was recorded after filtration using ABR and MF technologies. The new BOD levels obtained are within the WHO domestic wastewater standards (Figure 6B).

\subsection{COD (Chemical Oxygen Demand)}

COD refers to the amount of oxygen required in water to support the decomposition reactions of chemical pollutants and is expressed in ppm (parts per million) or mg/L [16] The measurement of effluent COD is another form of measuring the oxygen demand in wastewater. The greywater's COD levels measured using the spectrophotometric method were discovered to be quite high before filtration, at $655 \mathrm{mg} / \mathrm{L}, 509 \mathrm{mg} / \mathrm{L}$, and $284 \mathrm{mg} / \mathrm{L}$, for samples AL 1, AL 2, and AL 3, respectively [12]. These values do not fulfill the WHO wastewater standard threshold (100 mg/L).

A significant reduction in the COD levels to $184 \mathrm{mg} / \mathrm{L}$ and $152 \mathrm{mg} / \mathrm{L}$, for samples AL 1and AL 2, respectively, was recorded after greywater filtration using $\mathrm{ABR}$ and $\mathrm{MF}$ technologies. These new values also exceed the WHO wastewater standard threshold of $100 \mathrm{mg} / \mathrm{L}$. However, the results confirm filtration using ABR and MF technologies effectively reduces the COD of wastewater (Figure 6C).

\subsection{TSS (Total Suspended Solid)}

TSS is a measure of the solids responsible for turbidity, which are not dissolved, do not settle immediately, and comprise particles of smaller size and weight, compared to sediment [16]. A TSS value above the standard threshold is bound to cause sedimentation, thereby reducing the carrying capacity of rivers or water bodies [33]. In this study, the TSS evaluation of greywater using the gravimetric method showed the TSS levels exceed the WHO standard threshold [11] at $464.65 \mathrm{mg} / \mathrm{L}, 404.40 \mathrm{mg} / \mathrm{L}$, and $181.63 \mathrm{mg} / \mathrm{L}$, for samples AL 1, AL 2, and AL 3, respectively.

A significant reduction in the TSS levels to $77.42 \mathrm{mg} / \mathrm{L}$ and $59.68 \mathrm{mg} / \mathrm{L}$ was observed for samples AL 1 and AL 2, respectively. These values also exceed the WHO wastewater standard threshold of $30 \mathrm{mg} / \mathrm{L}$. However, these results confirm filtration using ABR and MF technologies effectively reduces the TSS of wastewater (Figure 6D).

\section{Conclusions}

Based on this study's findings, a greywater filter using ABR and MF technologies with $\mathrm{AC}$ and $\mathrm{CC}$ as the main materials, effectively reduces the turbidity, BOD, COD, and TSS levels, while increasing the $\mathrm{pH}$ of the wastewater. The BOD levels were reduced from $49.98 \mathrm{mg} / \mathrm{L}$ and $54.88 \mathrm{mg} / \mathrm{L}$ to $19.4 \mathrm{mg} / \mathrm{L}$ and $17.80 \mathrm{mg} / \mathrm{L}$, for samples AL 1 and AL 2, respectively. These results have fulfilled the WHO standard threshold of $30 \mathrm{mg} / \mathrm{L}$. Similarly, the COD levels reduced from $655 \mathrm{mg} / \mathrm{L}$ and $509 \mathrm{mg} / \mathrm{L}$ to $184 \mathrm{mg} / \mathrm{L}$ and $152 \mathrm{mg} / \mathrm{L}$, for samples AL 1 and AL 2, respectively. The TSS levels also reduced from $464.65 \mathrm{mg} / \mathrm{L}$ and 404, $40 \mathrm{mg} / \mathrm{L}$, to $77.42 \mathrm{mg} / \mathrm{L}$ and $59.68 \mathrm{mg} / \mathrm{L}$, for samples AL 1 and AL 2, respectively. The new COD and TSS values obtained still exceed the WHO standard threshold for greywater; however, these results confirm greywater filtration using ABR and MF technologies effectively reduces the COD and TSS levels of wastewater. In addition, the materials for manufacturing the greywater filter are easily obtainable, inexpensive, and can be developed independently; therefore, this tool is an implementation of portable filtration with low-cost production. 


\begin{abstract}
Author Contributions: Conceptualization: Z.S. and S.Y.; methodology: Z.S.; software: R.J.; validation: A.A., Z.S., and S.Y.; formal analysis: R.U.; investigation: A.A.; resources: K.P.; data curation: A.A.; writing—original draft preparation: A.A.; writing—review and editing: R.U.; visualization: R.P.; supervision: S.Y.; project administration: A.A.; funding acquisition: Z.S. All authors have read and agreed to the published version of the manuscript.
\end{abstract}

Funding: This research received no external funding.

Institutional Review Board Statement: Not applicable.

Informed Consent Statement: Not applicable.

Data Availability Statement: Data available in a publicly accessible repository.

Acknowledgments: The authors are grateful to the anonymous reviewers for their valuable comments and efforts to improve this manuscript.

Conflicts of Interest: The authors declare no conflict of interest concerning the publication of this article. The authors also confirm that the data and the article are free of plagiarism.

\title{
References
}

1. Easton, Z.M.; Bock, E. Hydrology Basics and the Hydrologic Cycle; Virginia Cooperative Extension: Blacksburg, VA, USA, 2015; pp. 1-9. Available online: https://ext.vt.edu/content/dam/ext_vt_edu/topics/agriculture/water/documents/HydrologyBasics-and-the-Hydrologic-Cycle.pdf (accessed on 10 October 2021).

2. Chorus, I.; Bartram, J. Toxic Cyanobacteria in Water: A Guide to Their Public Health Consequences, Monitoring and Management; E \& FN Spon, an Imprint of Routledge: London, UK, 1999; Volume 95, ISBN 0419239308.

3. Gordon, B.; Callan, P.; Vickers, C. WHO guidelines for drinking-water quality. WHO Chron. 2008, 38, 564. [CrossRef]

4. Custodio, E. Trends in Groundwater Pollution: Loss of Groundwater Quality E Related Services; Technical University of Catalonia: Barcelona, Spain, 2015.

5. Thommes, M.; Kaneko, K.; Neimark, A.V.; Olivier, J.P.; Rodriguez-Reinoso, F.; Rouquerol, J.; Sing, K.S.W. Physisorption of gases, with special reference to the evaluation of surface area and pore size distribution (IUPAC Technical Report). Pure Appl. Chem. 2015, 87, 1051-1069. [CrossRef]

6. Jung, H.; Koh, D.C.; Kim, Y.S.; Jeen, S.W.; Lee, J. Stable isotopes of water and nitrate for the identification of groundwater flowpaths: A review. Water 2020, 12, 138. [CrossRef]

7. Khalekuzzaman, M.; Alamgir, M.; Hasan, M.; Hasan, M.N. Performance comparison of uninsulated and insulated hybrid anaerobic baffled reactor (HABR) operating at warm temperature. Water Sci. Technol. 2018, 78, 1879-1892. [CrossRef]

8. Nakagawa, K.; Amano, H.; Berndtsson, R. Spatial characteristics of groundwater chemistry in Unzen, Nagasaki, Japan. Water 2021, 13, 426. [CrossRef]

9. Teixeira, C.A.; Ghisi, E. Comparative analysis of granular and membrane filters for rainwater treatment. Water 2019, 11, 1004. [CrossRef]

10. Asian Development Bank. Country Water Assessment Indonesia Country Water Assessment; Asian Development Bank: Mandaluyong, Philippines, 2016; ISBN 978-92-9257-360-7.

11. World Health Organization. A Compendium of Standards for Wastewater Reuse in the Eastern Mediterranean Region World Health Organization Regional Office for the Eastern Mediterranean Regional Centre for Environmental Health Activities CEHA; World Health Organization: Geneva, Switzerland, 2006; p. 19. Available online: http://applications.emro.who.int/dsaf/dsa1184.pdf (accessed on 10 October 2021).

12. Liu, L.; Li, Y.; Fan, S. Preparation of $\mathrm{KOH}$ and $\mathrm{H} 3 \mathrm{PO} 4$ modified biochar and its application in methylene blue removal from aqueous solution. Processes 2019, 7, 891. [CrossRef]

13. Li, J.; Zhou, Q.; Campos, L.C. The application of GAC sandwich slow sand filtration to remove pharmaceutical and personal care products. Sci. Total Environ. 2018, 635, 1182-1190. [CrossRef] [PubMed]

14. Lin, T.; Chen, W.; Wang, L. Particle properties in granular activated carbon filter during drinking water treatment. J. Environ. Sci. 2010, 22, 681-688. [CrossRef]

15. Siwila, S.; Brink, I.C. Drinking water treatment using indigenous wood filters combined with granular activated carbon. J. Water Sanit. Hyg. Dev. 2019, 9, 477-491. [CrossRef]

16. Telgote, A.R.; Patil, S.S. Study and Application of Various Activated Carbons and Ash used in Water Purification Techniques: A Review. Curr. World Environ. 2020, 15, 384-397. [CrossRef]

17. Mason, A.; Korostynska, O.; Wylie, S.; Al-Shamma'a, A.I. Non-destructive evaluation of an activated carbon using microwaves to determine residual life. Carbon 2014, 67, 1-9. [CrossRef]

18. Mopoung, S.; Moonsri, P.; Palas, W.; Khumpai, S. Characterization and Properties of Activated Carbon Prepared from Tamarind Seeds by KOH Activation for Fe(III) Adsorption from Aqueous Solution. Sci. World J. 2015, 2015, 415961. [CrossRef] [PubMed]

19. Sim, K.M.; Kim, K.H.; Hwang, G.B.; Seo, S.C.; Bae, G.N.; Jung, J.H. Development and evaluation of antimicrobial activated carbon fiber filters using Sophora flavescens nanoparticles. Sci. Total Environ. 2014, 493, 291-297. [CrossRef] 
20. Reungoat, J.; Escher, B.I.; Macova, M.; Argaud, F.X.; Gernjak, W.; Keller, J. Ozonation and biological activated carbon filtration of wastewater treatment plant effluents. Water Res. 2012, 46, 863-872. [CrossRef]

21. Ghosh, S.; Mondal, A.; Gangopadhyay, S.; Mandal, S. Cadmium bioaccumulation in Lamellidens marginalis and human health risk assessment: A case study in India. Hum. Ecol. Risk Assess. 2020, 26, 713-725. [CrossRef]

22. Sweetman, M.; May, S.; Mebberson, N.; Pendleton, P.; Vasilev, K.; Plush, S.; Hayball, J. Activated Carbon, Carbon Nanotubes and Graphene: Materials and Composites for Advanced Water Purification. J. Carbon Res. C 2017, 3, 18. [CrossRef]

23. Dvorak, B.I. Drinking Water Treatment: Activated Carbon Filtration; Institute of Agriculture and Natural Resources, University of Nebraska-Lincoln Extension: Lincoln, NE, USA, 2013; pp. 1-4.

24. Arshad, M.; Guillaume, J.H.A.; Ross, A. Assessing the feasibility of managed aquifer recharge for irrigation under uncertainty. Water 2014, 6, 2748-2769. [CrossRef]

25. Stoquart, C.; Servais, P.; Bérubé, P.R.; Barbeau, B. Hybrid Membrane Processes using activated carbon treatment for drinking water: A review. J. Membr. Sci. 2012, 411-412, 1-12. [CrossRef]

26. Jeong, H.; Kim, H.; Jang, T. Irrigation water quality standards for indirect wastewater reuse in agriculture: A contribution toward sustainablewastewater reuse in South korea. Water 2016, 8, 169. [CrossRef]

27. Mosbah, M.B.; Mechi, L.; Khiari, R.; Moussaoui, Y. Current state of porous carbon for wastewater treatment. Processes 2020, 8 , 1651. [CrossRef]

28. Vo, A.T.; Nguyen, V.P.; Ouakouak, A.; Nieva, A.; Doma, B.T.; Tran, H.N.; Chao, H.P. Water Efficient Removal of Cr(VI) from Water by Biochar and Activated Carbon Prepared through Hydrothermal Carbonization and Pyrolysis: Adsorption-Coupled Reduction Mechanism. Water 2019, 11, 1164. [CrossRef]

29. Cescon, A.; Jiang, J.Q. Filtration process and alternative filter media material in water treatment. Water 2020, 12, 3377. [CrossRef]

30. Furuya, K.; Harada, K. An automated precise Winkler titration for determining dissolved oxygen on board ship. J. Oceanogr. 1995, 51, 375-383. [CrossRef]

31. Benramache, S.; Aoun, Y. Spin Coating Method Fabricated of $\operatorname{In}_{2} \mathrm{O}_{3}$ Thin Films. Ann. West Univ. Timisoara Phys. 2019, 61, 56-63. [CrossRef]

32. Hayase, N.; Kitaoka, Y.; Yakou, Y.; Yoshida, T.; Ishimaru, K.; Yasuno, K. Characteristics of Biological Actived Carbon Filtration and Biological Filtration in Drinking Water Treatment. J. Jpn. Soc. Water Environ. 1998, 21, 507-512. [CrossRef]

33. Sabara, Z.; Junaidi, R.; Umam, R. Robust Decision Making(RD) Investiation in Water Resources Planning and Disaster Mitigation in Makassar City, Indonesia. J. Pertahanan 2018, 4, 61-75. 